\title{
RESUSCITATION AT THE PLACE OF ACCIDENT AND DURING TRANSPORTATION
}

\author{
F. W. AHNEFElD, M.D., R. FreY, M.D., F.F.A.R.C.S., M. HALMÁgYi, M.D., \\ AND H. NOLTE, M.D., D.A.*
}

THE PRIMARY TREATMENT and transportation of all emergency patients is governed by identical principles, irrespective of the cause of their condition. A standard type of ambulance would therefore be desirable. With a minimum of expense this type should meet all the conditions necessary for the treatment and transportation of emergency patients. The ambulance must be similar to a hospital emergency ward on wheels in which the attendant and, in special cases, a physician are able to perform the necessary treatment and resuscitation. Some requirements in the design and equipment of emergency ambulances may be discussed from the medical point of view:

1. The design of the rear compartment must ensure that, in general, only one patient is transported. He should be accessible at his head and at both sides of his body. But it may be desirable to permit the transportation of two patients who will then, however, be accessible at the head and from one side only.

2. The desirable dimensions for the rear compartment of ambulances differ from country to country. They include the length, width, and height of the inner compartment. The German Committee for Industrial Standards recommends in DIN 75080 (Fig. 1) a length of $3.00 \mathrm{~m}$. (minimum 2.65), a width of $1.70 \mathrm{~m}$. (minimum 1.50), and a height of $1.73 \mathrm{~m}$. (minimum 1.65). According to our own experiences, ambulances of these inner dimensions fulfil all requirements for the proper treatment of emergency patients of every kind. Besides the normal equipment, some special apparatus can be placed in the ambulance (small-sized respirators, defibrillators, etc.).

3. Unfortunately, there are various stretchers to be found, even in a single country. Therefore it is necessary to design a type of stretcher which can be placed in every ambulance. The recommendations of the Special Committee of the Danish National Health Service are completely acceptable: The stretcher's upper edge should be at least $65 \mathrm{~cm}$. above the floor of the ambulance (Fig. 2) to enable the required treatment (e.g., cardiopulmonary resuscitation). It should be possible to place the patient on the stretcher in a head-up and headdown position of $30^{\circ}$. The lowering of the head-down position should be possible in steps from $0^{\circ}$ to $30^{\circ}$ (Fig. 3).

4. The equipment should be built up in a module system. Module 1 contains everything needed for the treatment done by the rescuer. Module 2 is restricted to use by medical personnel. Most of the equipment has to be portable for use

'Institute of Anaesthesiology, Johannes Gutenberg University, Mainz. Dr. Frey is director of the Institute. 


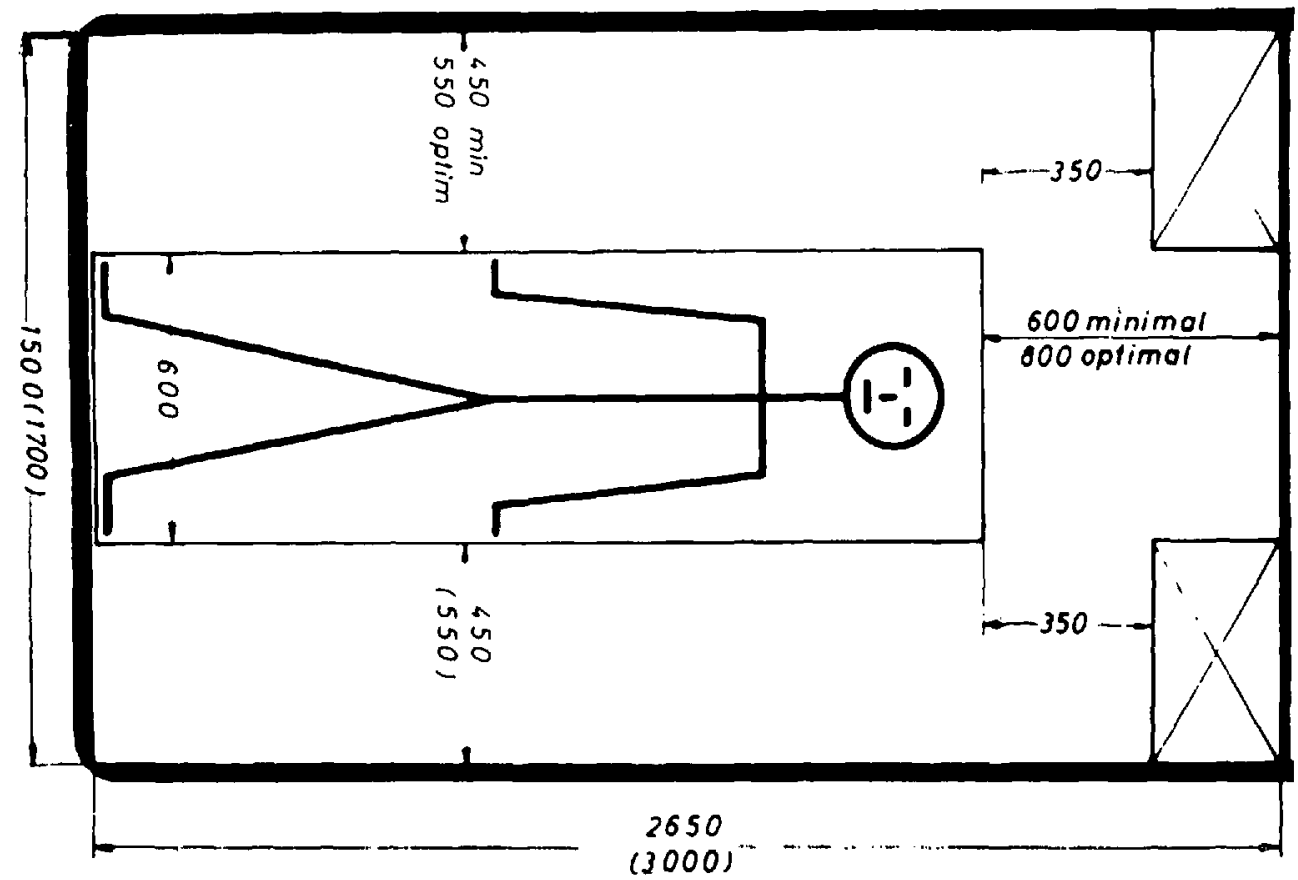

Figure 1. Working room of the emergency ambulance. Minimal requirements and, in parentheses, optimal requirements, are given in millimetres.

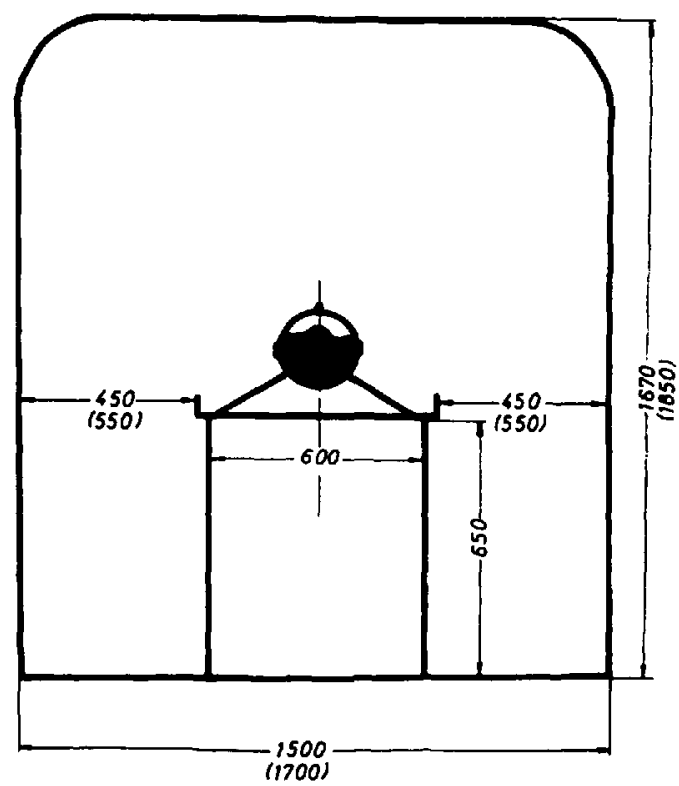

Frgure 2. A view of the working room as seen from the anaesthetist's place at the head of the patient. 


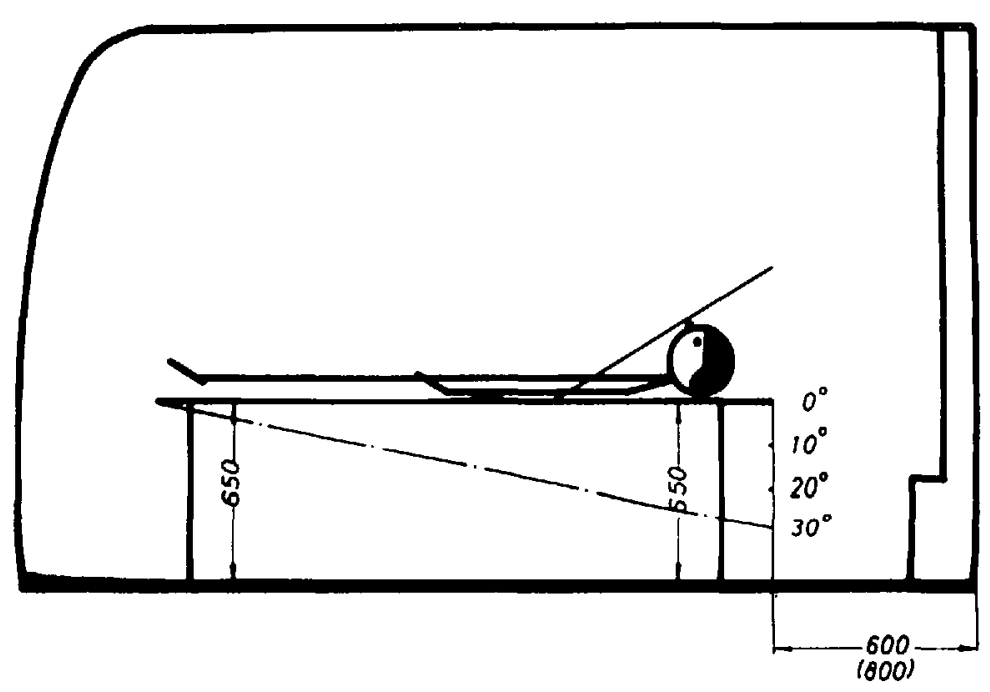

FIgURE 3. Lateral view of the working room.

outside of the ambulance. A summary of the essential requirements for equipment of emergency ambulances are given in Table I.

At the Institute of Anaesthesiology at Mainz University we have tested different types of ambulances lent to the Institute by the German Red Cross. The expenses for personnel, gasoline, equipment, etc. are covered by the State Government of Rheinland-Pfalz and the German Army. Some grants are given by insurance companies. The crew is composed of an anaesthesiologist, an anaesthesia nurse, and a professional rescuer as the driver. They are on duty around the clock and are ready to move out at any time. The car is called by a central dispatching system of the Red Cross, but only for patients in danger of life (unconscious, shocked, etc.). Since 1965 the following ambulances have been tested:

1. An Opel Blitz designed by Miesen Ltd. (Bonn). This ambulance had a rear compartment with a length of $5 \mathrm{~m}$., width $2.1 \mathrm{~m}$., and height $2 \mathrm{~m}$. The $70 \mathrm{HP}$ engine had a maximum speed of $95 \mathrm{~km}$./hour. The car was too big and too slow. Sometimes it was impossible to reach the place of emergency.

2. A 3/4-ton Matador designed by Miesen Ltd. (Bonn). The space in the rear compartment was acceptable but the equipment could not be placed in a convenient manner. The distance from the head of the victim to the wall was only $40 \mathrm{~cm}$. Furthermore, the speed could not exceed $85 \mathrm{~km}$./hour.

3. A Mercedes $408 \mathrm{~L}$ designed by Binz Ltd. (Stuttgart). The space of the compartment and the speed were convenient. At present a modification of the Mercedes $408 \mathrm{~L}$ is being tested, designed by Binz Ltd. (Ellwangen/Jagst).

In the near future two other types of ambulance will be stationed at the hospital. The first one is a 1/2-ton Matador designed by Hanau Clinomobil Ltd., Hannover (Figs. 4-6), and the second one is a $\%$-ton Volkswagen, from the same producer. These ambulances are expected to be most useful. 
TABLE I

\begin{tabular}{|c|c|c|}
\hline & Module 1 & Module 2 \\
\hline \multicolumn{3}{|l|}{ Respiration } \\
\hline 1. Free airway & $\begin{array}{l}\text { Suction equipment: suction } \\
\text { capacity in short bursts } \\
\text { at least } 300 \mathrm{~mm} \text {. Hg nega- } \\
\text { tive pressure desirable } \\
\text { Additional suction equip- } \\
\text { ment driven by electricity } \\
\text { or engine }\end{array}$ & $\begin{array}{l}\text { Emergency intubation set } \\
\text { Emergency tracheotomy set }\end{array}$ \\
\hline $\begin{array}{l}\text { 2. Re-establishment and } \\
\text { maintenance of } \\
\text { respiration }\end{array}$ & $\begin{array}{l}\text { Portable hand-operated } \\
\text { self-inflating bag and } \\
\text { mask units with connec- } \\
\text { tion for oxygen } \\
\text { Two } 3 \text { L. oxygen cylinders } \\
\text { One portable oxygen inhaler } \\
\text { Three Guedel airways, sizes } \\
2,3,5 \\
\text { One Orotubus for mouth-to- } \\
\text { mouth resuscitation }\end{array}$ & \\
\hline $\begin{array}{l}\text { Haemorrhage and shock } \\
\text { treatment }\end{array}$ & $\begin{array}{l}\text { Bandage material for } \\
\text { compresses } \\
\text { Four triangular bandages } \\
\text { (Tourniquet) }\end{array}$ & $\begin{array}{l}\text { Two Kocher's clips } \\
\text { Plasma expanders with infu- } \\
\text { sion sets } 4 \times 500 \mathrm{ml} \text {. } \\
\text { One injection set (disposable) } \\
\text { Two } 10 \mathrm{ml} \text {. syringes } \\
\text { Two } 5 \mathrm{ml} \text {. syringes } \\
\text { Two } 2 \mathrm{ml} \text {. syringes } \\
\text { One compartment for circula- } \\
\text { tory stimulants and } \\
\text { analgesics }\end{array}$ \\
\hline Cardiac resuscitation & $\begin{array}{l}\text { Hard flat surface for thoracic } \\
\text { portion of stretcher (may } \\
\text { be necessary to neutralize } \\
\text { stretcher springs) }\end{array}$ & $\begin{array}{l}\text { Compartment for cardiac } \\
\text { stimulants } \\
\text { Cardiac puncture cannulae } \\
\text { desirable } \\
\text { One defibrillator (independent } \\
\text { of mains, D.C.) }\end{array}$ \\
\hline Miscellaneous equipment & $\begin{array}{l}\text { Bandages and splints } \\
\text { Technical rescue equipment } \\
\text { One hand searchlight }\end{array}$ & $\begin{array}{l}\text { For special medical atten- } \\
\text { dance: one pocket set of } \\
\text { surgical instruments } \\
\text { sufficient for: (a) venous } \\
\text { cutdown, (b) emergency } \\
\text { amputation, (c) puncture of } \\
\text { major cavities; two sterile } \\
\text { pneumothorax needles; two } \\
\text { pairs of rubber gloves; one } \\
\text { i.v. anaesthetic }\end{array}$ \\
\hline
\end{tabular}

In a total of nearly 200 emergency calls (see Fig. 7) we found that the patients could be classified as shown in Table II. The survey shows that the medical patients were more frequent than the surgical and that transportation was necessary (1) from place of accident to clinic, (2) from home to clinic, and (3) from small hospital to university clinic. The use of a helicopter was necessary during the same time in only six cases.

The treatments carried out are shown in Table III. Administration of oxygen, artificial ventilation, and a free airway are the most frequent demands in emergency cases. For this reason sufficient sources for oxygen and suction and the facilities for artificial ventilation are obligatory in ambulances. This kind of treatment can be carried out by paramedical personnel. 


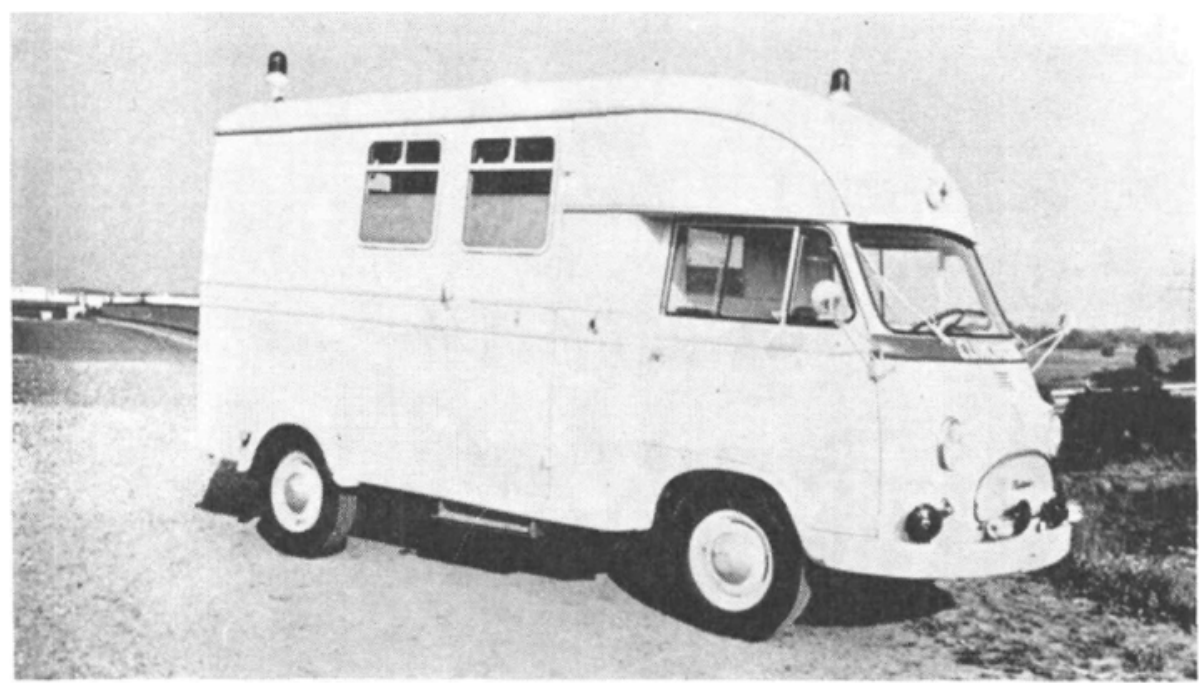

FiGure 4. An emergency ambulance designed by Hanau-Clinomobil Ltd., Hannover, Germany.

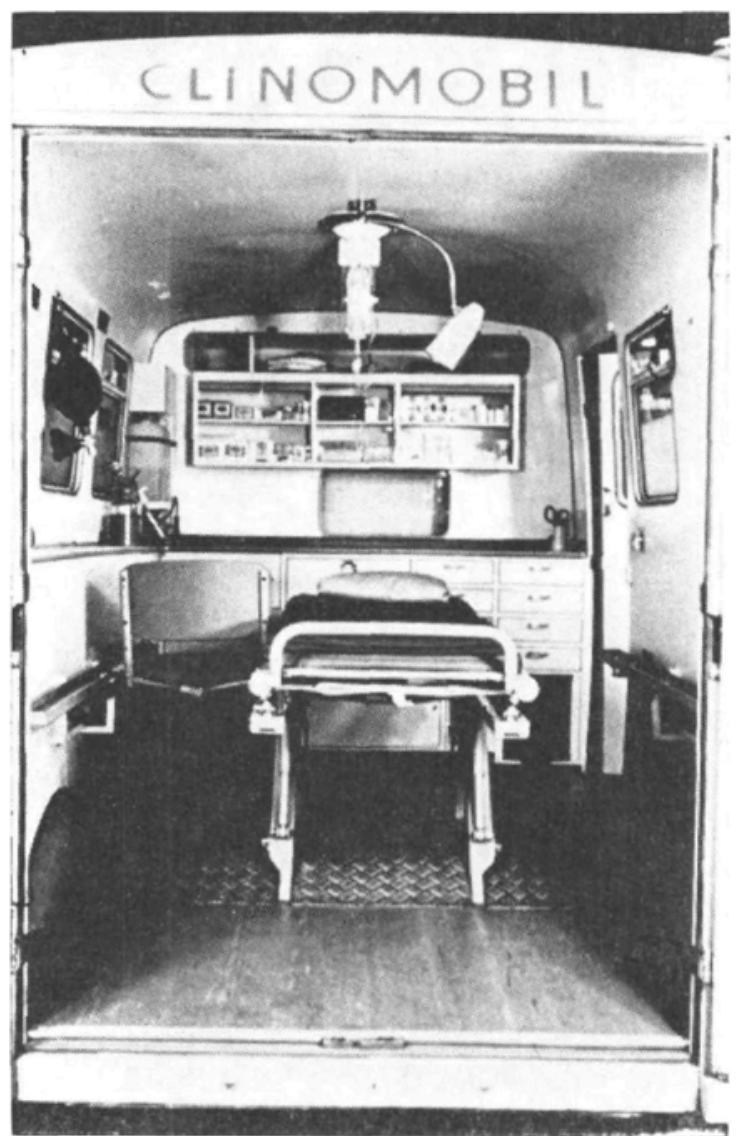

Figure: 5. Position of one stretcher inside the ambulance. 


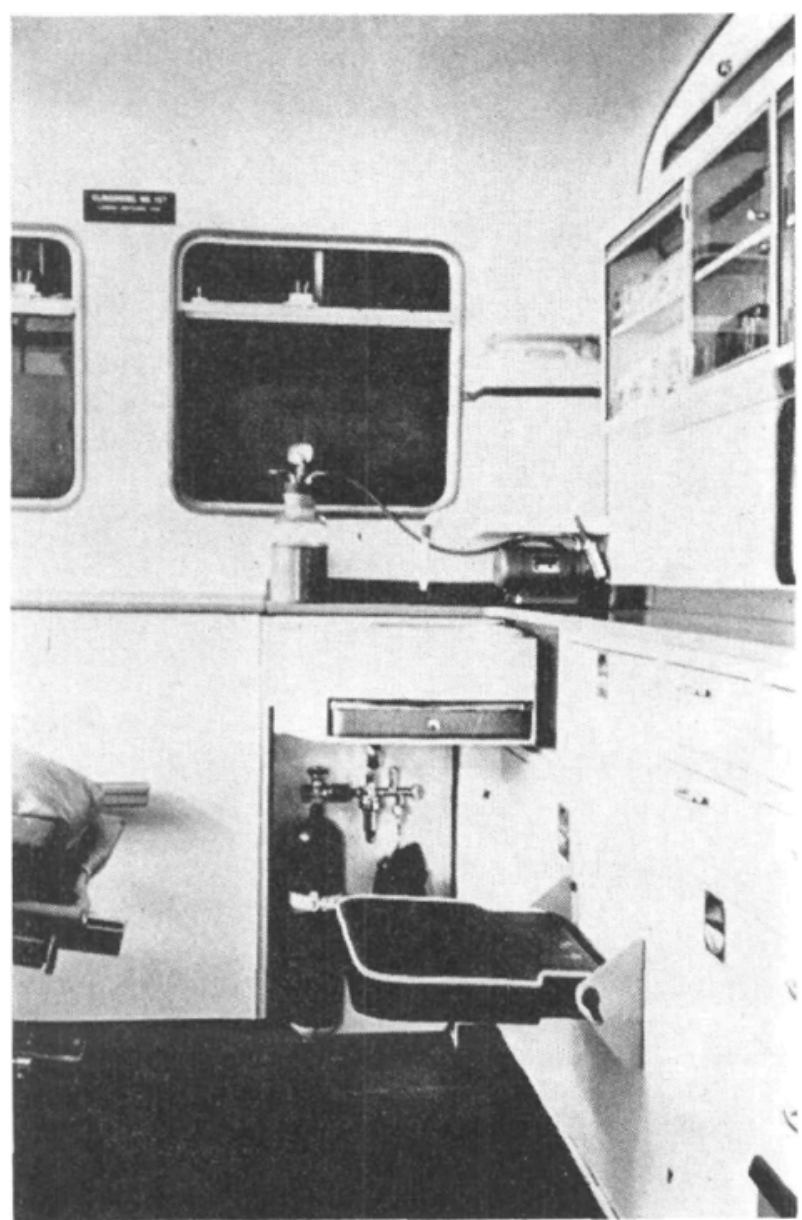

Figure 6. The anaesthetist's position at the head of the patient.

TABLE II

\begin{tabular}{lcc}
\hline \hline Type of patient & Number & Per cent of total \\
\hline Surgical & 63 & 32.2 \\
Medical & 74 & 37.5 \\
Obstetrical & 11 & 5.7 \\
Psychiatric & 6 & 3.1 \\
Paediatric & 7 & 3.5 \\
Poisoned & 24 & 12.2 \\
Not transported & 11 & 5.7 \\
Total & 196 & 100.0 \\
\hline
\end{tabular}

As mentioned under Module 2 in Table I, a certain quantity of drugs and special equipment should be available. We followed up the 196 emergency calls and found out that the drugs listed in Table IV were necessary. A venous cutdown was done nine times. It was never necessary to carry out a tracheostomy. Besides the drugs mentioned, a short-acting barbiturate, calcium, and cedilanid are desirable. 


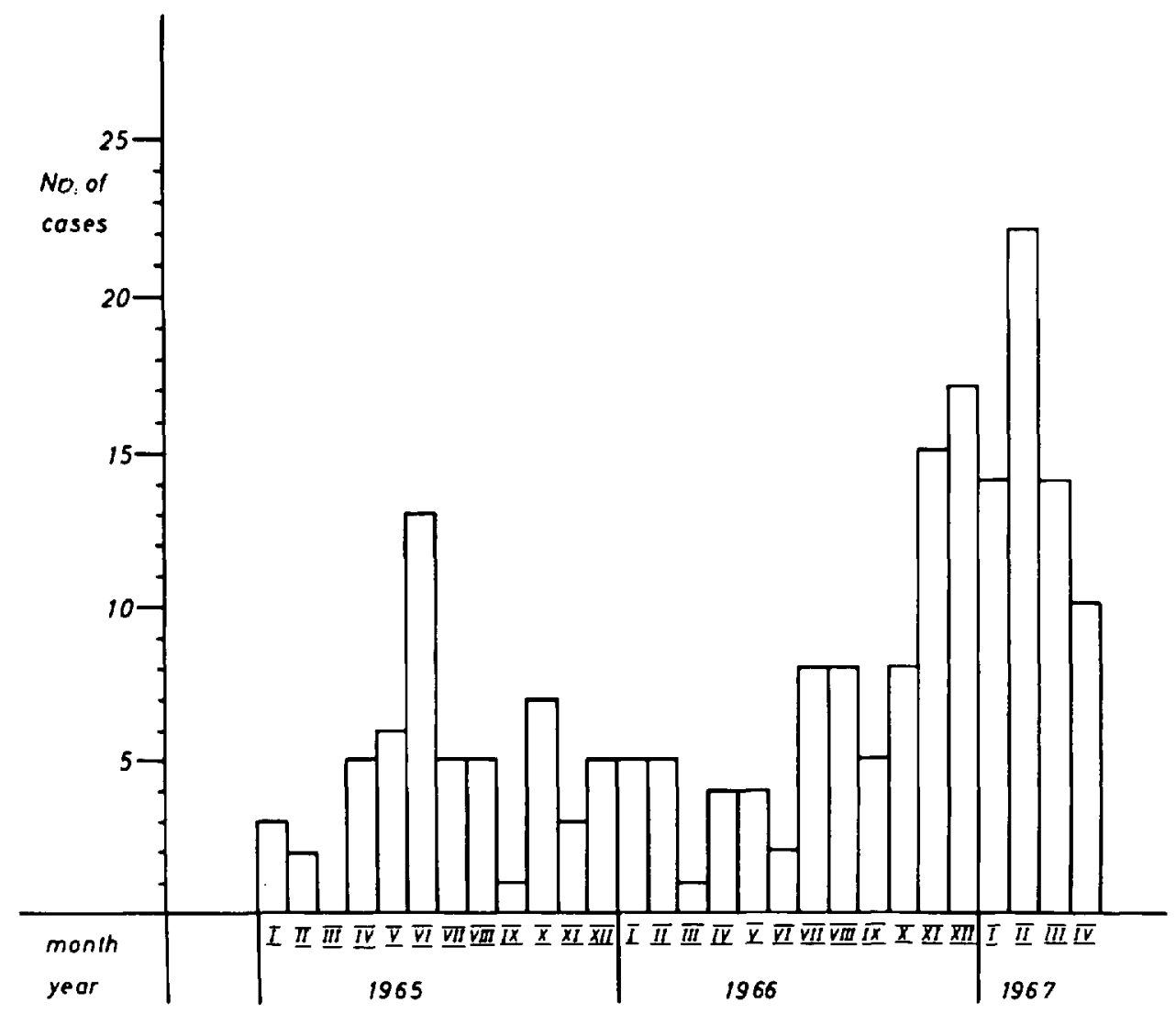

Figune 7. Frequency of emergency transportations at the University Hospital of Mainz, 1965-67.

TABLE III

\begin{tabular}{lc}
\hline \multicolumn{1}{c}{ Kind of treatment } & Number of cases \\
\hline Oxygen therapy & 63 \\
Intubation & 57 \\
Artificial ventilation & 46 \\
External cardiac massage & 29 \\
Endobronchial suctioning & 28 \\
Artificial airway & 23 \\
Decompression of pneumothorax & 4 \\
Obstetrical procedures & 2 \\
\hline
\end{tabular}

\section{Conclusion}

The best way to save lives is to start resuscitation at the scene of the accident and continue it during transportation to the hospital. Every university hospital should have one or, better, two emergency ambulance cars in the charge of the department of anaesthesia. Facilities for emergency service at the Medical Academy of Magdeburg are shown in Figures 8 and 9. 
TABLE IV

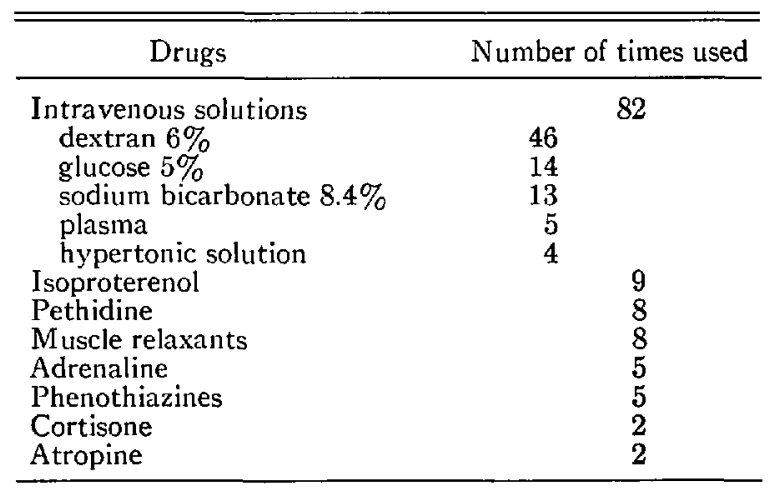

\section{SUMMARY}

Personal experiences in 200 emergency calls with different types of ambulance gave a chance to evaluate the modern possibilities of resuscitation at the place of accident and during transportation. The emergency ambulance of the future should have sufficient space in the rear compartment for the treatment of the patient.

The stretcher should facilitate every position required for the patient. Administration of oxygen, artificial ventilation, and suctioning should always be possible-even outside the ambulance. If a doctor accompanies the ambulance, plasma expanders, cardiac stimulants, analgesics, barbiturates, and cortisone should be available. Sets for intubation, venous cut-down, and pleural puncture should be at hand, but the most expensive and best-equipped ambulance can never replace the skill and experience of well-trained rescue personnel.

\section{RÉSUMÉ}

Une expérience personnelle de 200 appels d'urgence sur différents genres d'ambulances nous a permis d'évaluer les possibilités actuelles de réanimation, au lieu de l'accident et pendant le transport. A l'avenir, l'ambulance utilisée pour les urgences devrait avoir, dans le compartiment arrière, un espace suffisant pour le traitement du malade.

La civière devrait être assez maniable pour qu'on puisse placer le malade dans la position requise. Il devrait être possible en tout temps, même en dehors de l'ambulance, d'administrer de l'oxygène, de pratiquer la ventilation artificielle et l'aspiration. Si un médecin fait partie du personnel, il devrait avoir à sa disposition des substituts du plasma, des stimulants cardiaques, des analgésiques, des barbituriques et de la cortisone. On devrait avoir à portée de la main des nécessaires à intubation, à dissection veineuse et à ponction pleurale; il n'en reste pas moins que l'ambulance la plus couteuse et la mieux équipée ne peut jamais remplacer l'habileté et l'expérience d'un personnel bien entrainé. 

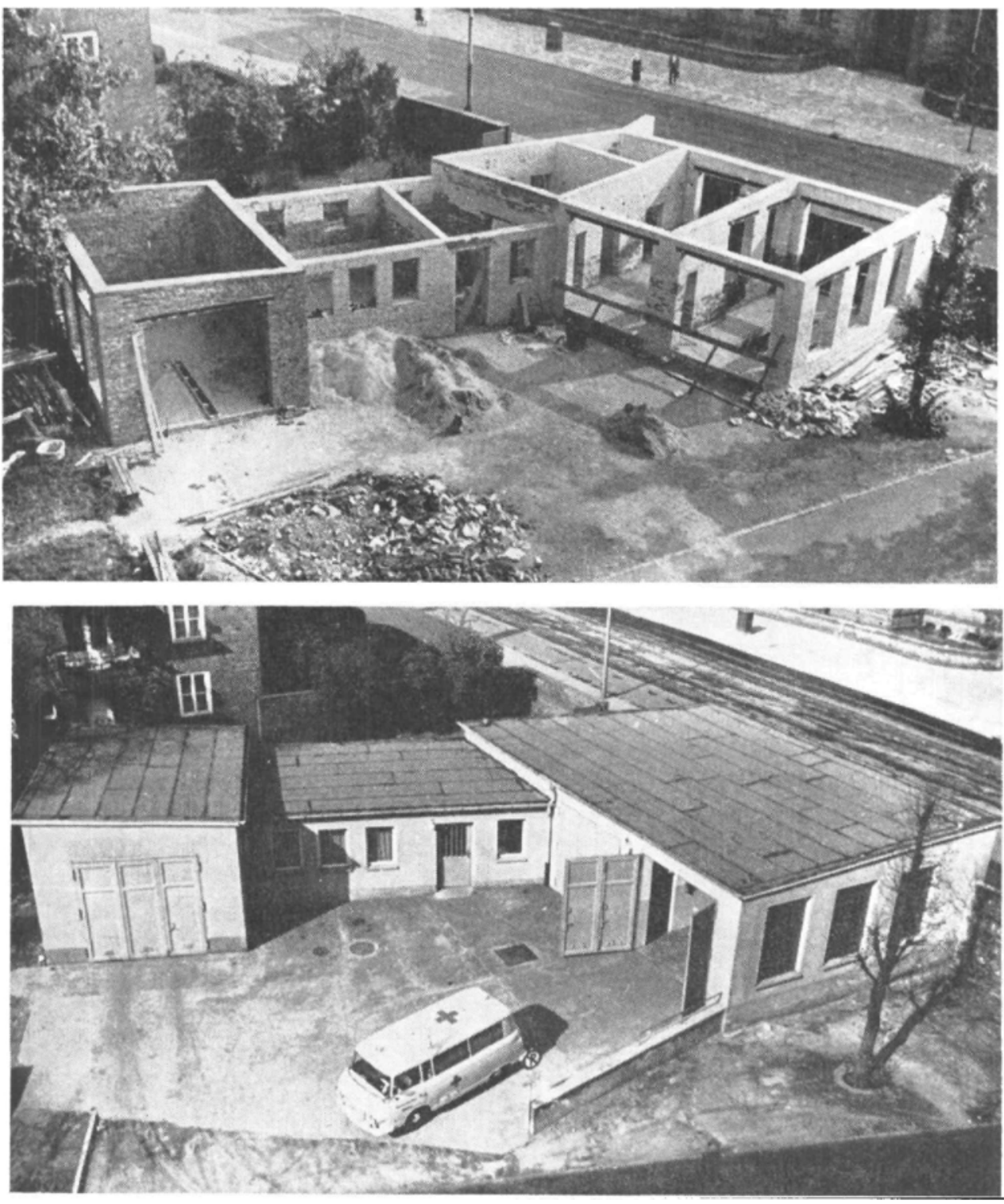

Figures 8 and 9. Buildings of the "Fast Aid" Service of the Medical Academy of Magdeburg. Above: in construction; below: in use. The cleaning garage is at left. In the centre are rooms for housing, sleeping, and bathing. At the right are two garages with side rooms. The road shown in the background is Leipziger Strasse, a main highway with direct entrance to both garages.

\section{ACKNOWLEDGMENTS}

We wish to thank Doctor Röse from the Department of Anaesthesia (Chief, Dr. med. habil. L. Wilken) of the Medical Academy of Magdeburg for advice, literature, and the photographs shown in Figures 8 and 9. 


\section{REFERENCES}

1. KäNDLER, W. \& H. Nolte. Erfahrungen mit dem Notarztwagen. Anaesthesist. 17: 22 (1968).

2. RösE, W. Schnelle Hilfe. Dtsch. Gesundheitswesen. 18: 143 (1963).

3. - - Der Anaesthesist am Unfallort. Anaesthesist. 13: 239 (1964).

4. - - Der Schädelverletzte aus der Sicht des Arztes am Unfallort. Der Chirurg. 35: 53 (1964).

5. -- - Das Schicksal des am Unfallort ärztlich versorgten Schädelhirnverletzten. Zentralbl. f.Chirurgie. 89: 369 (1964).

6. _-_ Zur Organisation der ärztlichen Ersthilfe bei Verkehrsunfällen in einer Grossstadt. Dtsch. Gesundheitswesen. 19: 1866 (1964). 